\title{
PEMANFAATAN APLIKASI E-KONSELING SEBAGAI PEDOMAN PELAKSANAAN KONSULTASI DAN PENGOBATAN UNTUK PENDERITA HIV
}

\section{APPLICATION OF E-COUNSELING AS GUIDELINE FOR THE IMPLEMENTATION OF CONSULTATION AND TREATMENT FOR PEOPLE WITH HIV}

\author{
Hairil Kurniadi Siradjuddin ${ }^{1}$, Saiful Do.Abdullah ${ }^{2}$ \\ Fakultas Teknik, Prodi Teknik Informatika \\ Universitas Khairun Ternate \\ hairil.kurniadi@unkhair.ac.id
}

\begin{abstract}
Abstrak
Pedoman Pelaksanaan Konseling dan Tes HIV wajib menjadi acuan bagi tenaga kesehatan, pengelola program, kelompok profesi yang menjadi konselor HIV, pengelola/pengurus tempat kerja, dan pemangku kepentingan terkait lainnya dalam penyelenggaraan Konseling dan Tes HIV. Konseling dan Tes HIV dilakukan dalam rangka penegakan diagnosis HIV dan AIDS, untuk mencegah sedini mungkin terjadinya penularanatau peningkatan kejadian infeksi HIV dan pengobatan lebih dini. Untuk menjawab permasalahan tersebut diatas, maka penulis melakukan riset dengan mengembangkan dan menerapkan aplikasi E-Counseling bebrbasis online sehingga mempermudah konseli dalam berkonsultasi dengan konselor. Implementasi Aplikasi e-Konseling untuk para penderita HIV sangat bermanfaat, karena menjadi alat komunikasi yang sangat penting bagi penderita yang akan melakukan konslutasi. Tersedianya fitur khusus untuk Konselor, sehingga, pengguna aplikasi lebih cepat mendapatkan informasi, karena konselor bisa langsung menjawab pertanyaan dengan respon cepat, karena bisa diakses dari mana saja.

\section{Kata kunci: HIV, e-Konseling, Internet}

\begin{abstract}
Guidelines for Implementing HIV Counseling and Testing must be a reference for health workers, program managers, professional groups who become HIV counselors, managers/workplace administrators, and other relevant stakeholders in organizing HIV counseling and testing. HIV counseling and testing are done in the context of establishing a diagnosis of HIV and AIDS, to prevent transmission as early as possible or increase the incidence of HIV infection and early treatment. To answer the above problems, the writer researches by developing and implementing an online application based on E-Counseling, making it easier for counselees to consult with counselors. Implementation of e-counseling applications for people living with HIV is beneficial because it becomes an essential communication tool for sufferers who will conduct counseling. The availability of unique features for counselors, so that application users can get information faster because counselors can directly answer questions with a quick response because it can be accessed from anywhere
\end{abstract} Keywords: HIV, e-Counseling, Internet 


\section{PENDAHULUAN}

Dunia online juga bisa dijadikan sarana bagi para konselor untuk meningkatkan pengetahuan dan membantu dalam mencari referensi, diskusi, pelajaran dan lain sebagainya.

Pedoman Pelaksanaan Konseling dan Tes HIV wajib menjadi acuan bagi tenaga kesehatan, pengelola program, kelompok profesi yang menjadi konselor HIV, pengelola/pengurus tempat kerja, dan pemangku kepentingan terkait lainnya dalam penyelenggaraan Konseling dan Tes HIV.

Konseling dan Tes HIV dilakukan dalam rangka penegakan diagnosis HIV dan AIDS, untuk mencegah sedini mungkin terjadinya penularanatau peningkatan kejadian infeksi HIV dan pengobatan lebih dini. Beberapa pendekatan dalam proses konseling dan Tes HIV, diantaranya:

(1) Konseling dan Tes HIV dilakukan melalui pendekatan:

a. Konseling dan Tes HIV atas Inisiatif Pemberi Pelayanan Kesehatan (KTIP); dan

b. Konseling dan Tes HIV Sukarela (KTS).

(2) Konseling dan Tes HIV atas Inisiatif Pemberi Pelayanan Kesehatan (KTIP) sebagaimana dimaksud pada ayat (1) huruf a merupakan tes HIV dan konseling yang dilakukan kepada seseorang untuk kepentingan kesehatan dan pengobatan berdasarkan inisiatif dari pemberi pelayanan kesehatan.

(3) Konseling dan Tes HIV Sukarela (KTS) sebagaimana dimaksud pada ayat (1) huruf $\mathrm{b}$ merupakan proses konseling sukarela dan tes HIV atas inisiatif individu yang bersangkutan.
Karena kompleksnya permasalahan yang dihadapi oleh para penderita HIV, menyebabkan sebagian penderita kurang aktif dalammelakukan konsultasi, dikarenakan tidaksemua penderita bisa terbuka dan terus terang kepada konselor apabila harus bertatapmuka dalam mengkonsultasikan kondisi kesehatannya.

Untuk menjawab permasalahan tersebut diatas, maka penulis melakukan riset dengan mengembangkan dan menerapkan aplikasi E-Counseling bebrbasis online sehingga mempermudah konseli dalam berkonsultasi dengan konselor

\section{Rumusan Masalah}

Berdasarkan uraian pada latar belakang masalah diatas, maka dapat dirumuskan pokok permasalahan penelitian adalah: Bagaimana merancang dan mengimplementasikan aplikasI pelayanan pedoman konsultasi bagi penderita HIV menggunakan aplikasi e-konseling

\section{LANDASAN TEORI \\ Pengertian Aplikasi}

Menurut Nazrudin Safaat H (2012 : 9) Perangkat lunak aplikasi adalah suatu subkelas perangkat lunak komputer yang memanfaatkan kemampuan komputer langsung untuk melakukan suatu tugas yang diinginkan pengguna. Biasanya dibandingkan dengan perangkat lunak sistem yang mengintegrasikan berbagai kemampuan komputer, tapi tidak secara langsung menerapkan kemampuan tersebut untuk mengerjakan suatu tugas yang menguntungkan pengguna. Contoh utama perangkat lunak aplikasi adalah pengolah kata, lembar kerja, dan pemutar media. 
Beberapa aplikasi yang digabung bersama menjadi suatu paket kadang disebut sebagai suatu paket atau suite aplikasi (application suite)

\section{e-Counseling}

Berikut beberapa pengertian $e$ Counseling menurut para ahli: Menurut Amani (2007) e-Counseling adalah adalah konseling yang dilakukan melalui internet yang secara umum merujuk pada profesi yang berkaitan dengan layanan kesehatan mental melalui teknologi komunikasi internet. Menurut Fields (2011) menyebutkan bahwa e-counseling merupakan sebuah layanan terapi yang relatif baru. Konseling dikembangkan dengan menggunakan teknologi komunikasi dari yang paling sederhana dengan menggunakan telepon maupun dari computer ke komputer hingga dengan menggunakan webcam (komputer dan internet). Menurut Haberstroh (2011) menjelaskan bahwa e-counseling adalah komunikasi antara klien dan konselor dengan menggunakan streaming video dan audio komputer sehingga tercipta komunisi antara klien dengan dengan konselor Dari beberapa pengertian diatas, dapat disimpulkan bahwa e-counseling adalah kegiatan membantu (terapi) yang dilakukan oleh seorang konselor terhadap masalah yang dihadapi oleh seorang klien dengan memanfaatkan teknologi informasi berupa komputer dan internet.

\section{Tahapan E-Counseling}

Tahapan dalam penerapan e-counseling dibutuhkan kebutuhan pendukung,selain memiliki keahlian dasar konseling, diperlukan hal-hal yang lain untuk menujang kelancaran proses konseling. Sebagaimana yang di kemukakan oleh Koutsonika (2009) yang menjelaskan bahwa proses konseling tidak semudah dan sesimple yang dibayangkan, sebab proses konseling memiliki kompleksitas permasalahan yang beragam dan isu yang berbeda tergantung karakteristik setiap klien, selain itu juga pengguna dihadapkan pada masalah etika dalam pengguanaan teknologi informasi, latar belakang pendidikan, hokum, keterampilan dan masalah manajemen

Ada beberapa cara dalam tahapan melakukan proses e-Counseling, seperti yang dikemukakan oleh Ifdil (2011), seperti gambar dibawah ini;

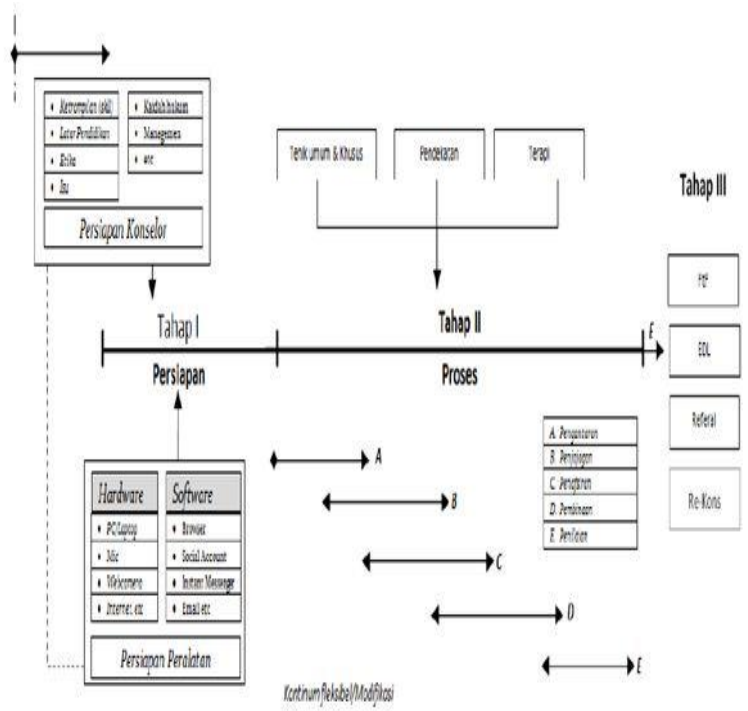

Gambar 1. Tahapan Proses E Counseling (Ifdil 2011)

\section{Unified Modelling Languange(UML)}

Menurut Fowler (2003, 14), Unified Modeling Language (UML) adalah keluarga dari notasi grafis dan didukung oleh metamodel tunggal, yang membantu dalam menggambarkan dan merancang sistem perangkat lunak, khususnya sistem software 
yang dibangun menggunakan berorientasi obyek (OO). Berikut beberapa tahapan rancangan diagram Model $U M L$

\section{Class Diagram}

Class diagram yaitu salah satu jenis diagram pada $U M L$ yang digunakan untuk menampilkan kelas-kelas maupun paket-paket yang ada pada suatu sistem yang nantinya akan digunakan. Jadi diagram ini dapat memberikan sebuah gambaran mengenai sistem maupun relasi-relasi yang terdapat pada sistem tersebut

\section{Use Case Diagram}

Use case diagram yaitu salah satu jenis diagram pada UML yang menggambarkan interaksi antara sistem dan aktor, use case diagram juga dapat men-deskripsikan tipe interaksi antara si pemakai sistem dengan sistemnya.

\section{Sequence Diagram}

Sequence diagram yaitu salah satu jenis diagram pada UML yang menjelaskan interaksi objek yang berdasarkan urutan waktu, sequence diagram juga dapat menggambarkan urutan atau tahapan yang harus dilakukan untuk dapat menghasilkan sesuatu seperti pada use case diagram

\section{Activity Diagram}

Activity diagram atau diagram aktivitas yaitu salah satu jenis diagram pada $U M L$ yang dapat memodelkan proses-proses apa saja yang terjadi pada sistem.

\section{METODE PENELITIAN}

Penelitian adalah suatu proses penyelidikan yang dilakukan secara sistematis yang bertujuan untuk menyelesaikan dan mendapatkan pemecahan masalah. (Cooper and Emory, 1995). Pada umumnya para peneliti menggunakan beberapa metode penelitian yang berbeda, akan tetapi yang sering digunakan terdiri dari empat metode, yaitu: metode eksperimen, metode tindakan penelitian, metode studi kasus dan metode survei. (Dawson, 2009).

\section{Alat dan Bahan yang digunakan}

Tabel 1. Alat dan Bahan

\begin{tabular}{|l|l|}
\hline \multicolumn{1}{|c|}{ Software } & \multicolumn{1}{c|}{ Hardware } \\
\hline $\begin{array}{l}\text { Sistem Operasi: } \\
\text { Windows } 7\end{array}$ & $\begin{array}{l}\text { CPU Dual Core } \\
\text { Processor C60 }\end{array}$ \\
\hline PHP My SQL & Memory: $2 \mathrm{~GB}$ \\
\hline $\begin{array}{l}\text { Macromedia } \\
\text { Dreamweaver } 8\end{array}$ & Hardisk: $500 \mathrm{~GB}$ \\
\hline Adobe Photoshp & Acces Point Outdoor \\
\hline Ms.VISIO & Mouse Optic \\
\hline
\end{tabular}

\section{Kerangka Penilitian}

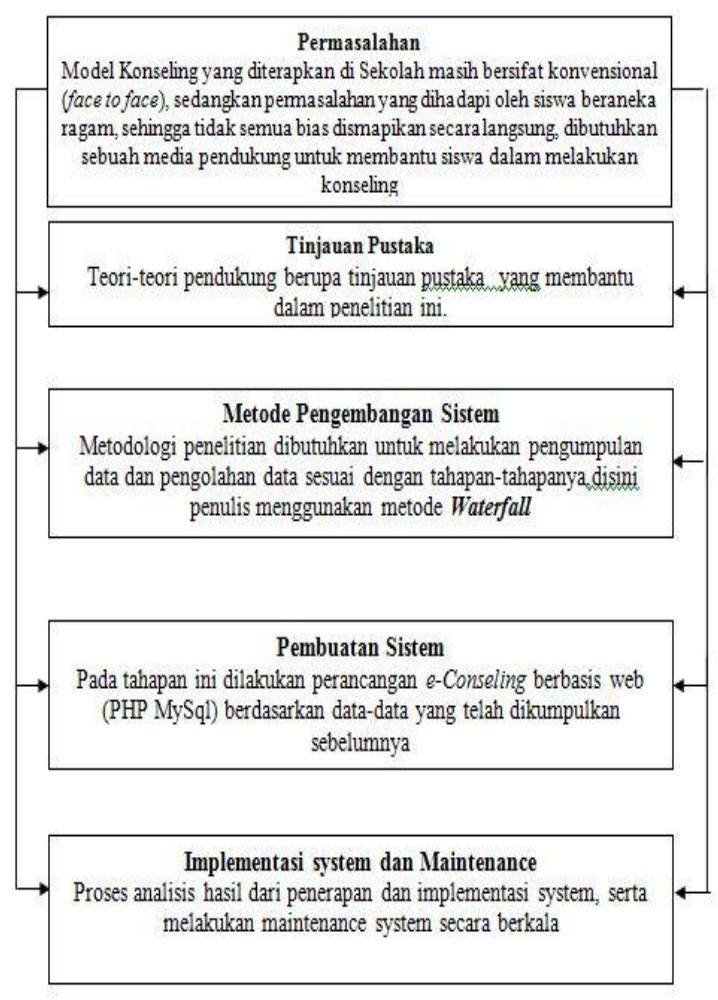

Gambar 2. Kerangka Penilitian 


\section{Analisa Sistem yang Berjalan}

Karena kompleksnya permasalahan yang dihadapi oleh para penderita HIV, menyebabkan sebagian penderita kurang aktif dalam melakukan konsultasi, dikarenakan tidak semua penderita bisa terbuka dan terus terang kepada konselor apabila harus bertatapmuka dalam mengkonsultasikan kondisi kesehatannya

\section{PERANCANGAN SISTEM}

\section{Rancangan Sistem Use Case Konselor}

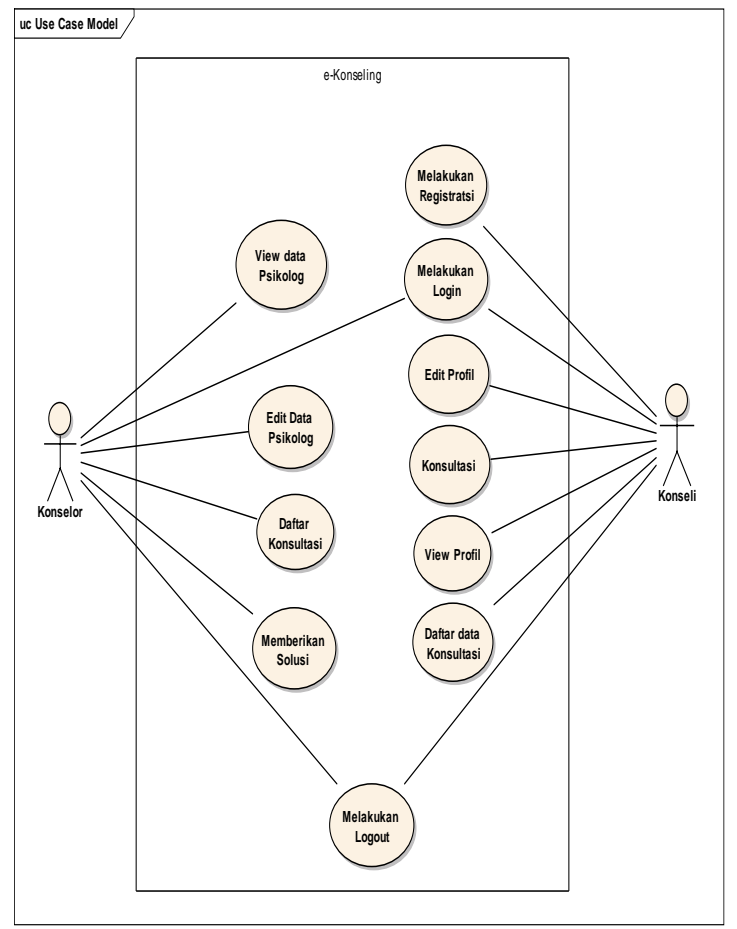

Gambar 3. Use Case Diagram Konselor

\section{Rancangan Sistem Use Case Admin}

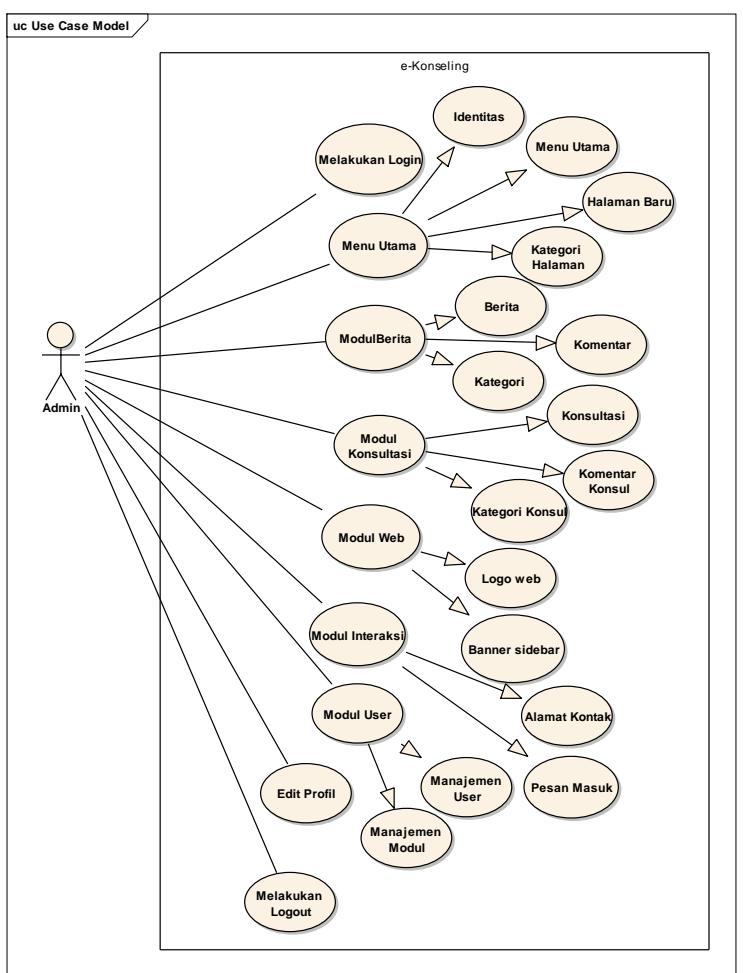

Gambar 4. Use Case Diagram Admin

\section{Arsitektur Sistem}

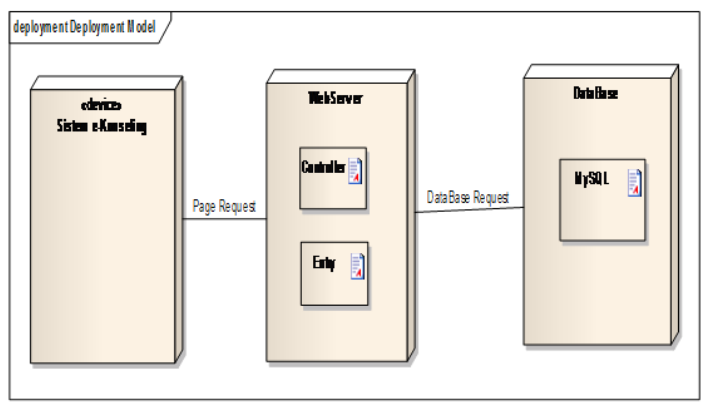

Gambar 5. Arsitektur Sistem

\section{Rancangan Database Sistem}

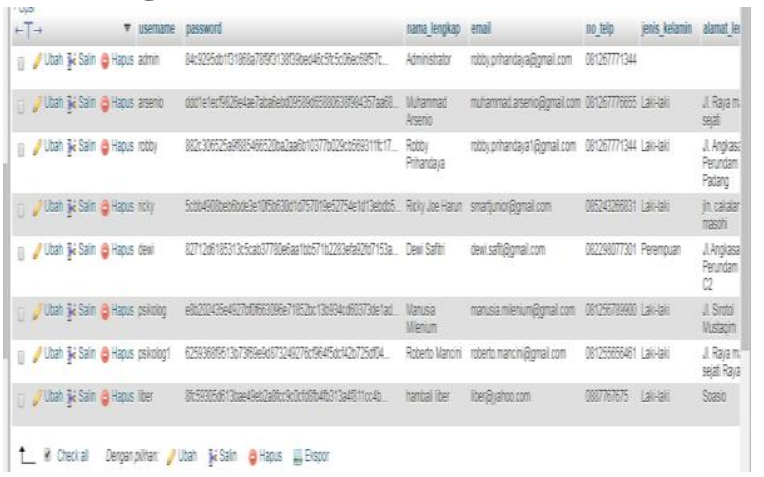

Gambar 6. Database Sistem 


\section{IMPLEMENTASI SISTEM}

Berikut adalah tampilan awal sistem eKonseling dengan menggunakan aplikasi berbasis web. Pengujian aplikasi e-Konseling dilengkapi dengan manual pemakain untuk setiap fungsi yang ada pada aplikasi ini. Langkah pertama dalam proses pengujian adalah menguji aplikasi yang dibuat dengan membuka browser Mozilla firefox dan mengetikan http://localhost/e-konseling maka akan muncul tampilan halaman awal pada gambar dibawah ini

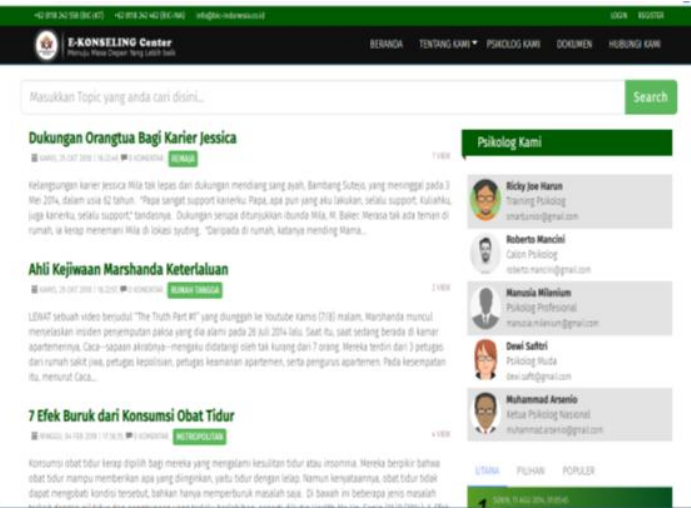

Gambar 7. Tampilan awal

Gambar dibawah ini adalah tampilan registrasi bagi konseli, dimana setiap pasien yang akan melakukan konsultasi harus melakukan registrasi untuk mendapatkan username dan password:

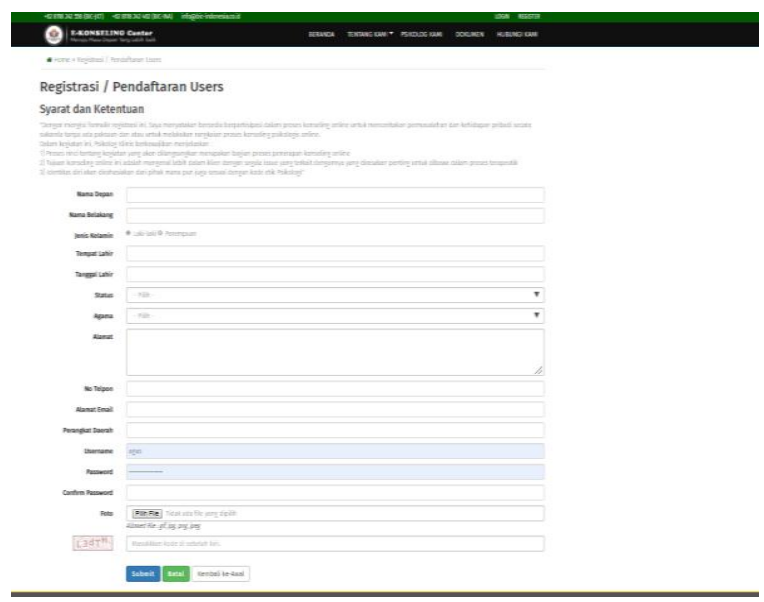

Gambar 8. Tampilan Registrasi
Tampilan gambar dibawah ini adalah halaman untuk melakukan login bagi klien, jika klien akan berkonsultasi harus login menggunakan username dan password yang didapatkan pada saat mendaftar

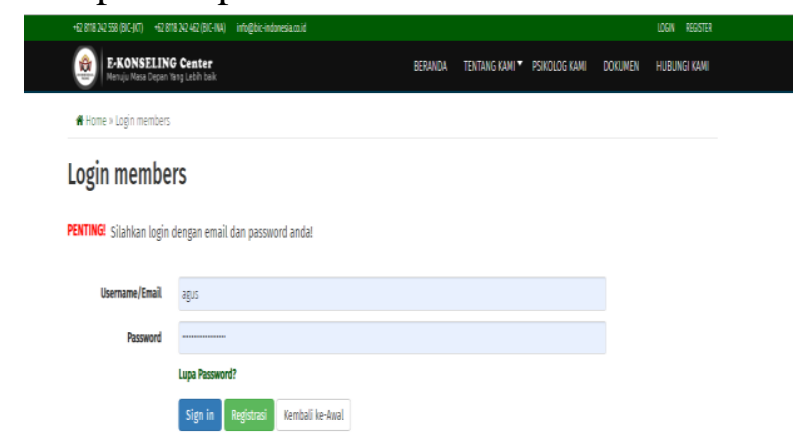

\section{Gambar 9. Tampilan Login Member}

Berikut tampilan halaman melakukan konsultasi menggunakan aplikasi ekonseiling, dimana setelah pasien berhasil melakukan login, maka klien bisa berkonsultasi dengan mengisi formulir konsultasi:

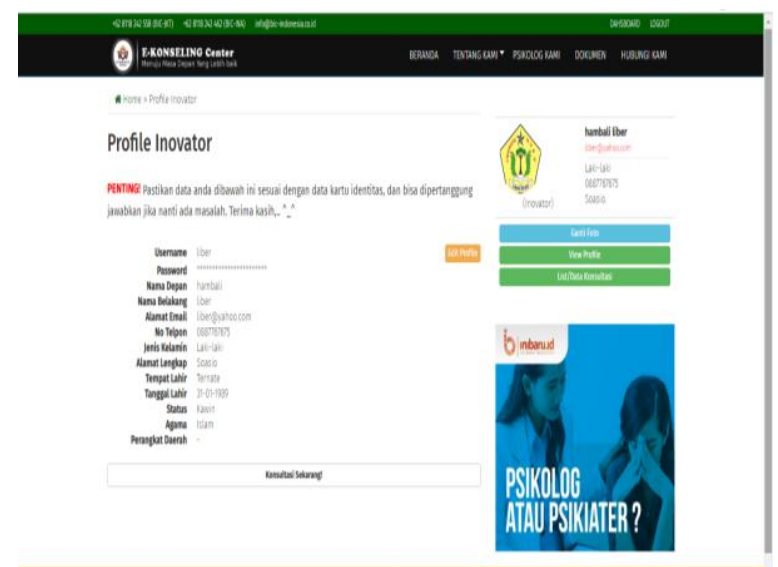

Gambar 10. Tampilan profil Member

Berikut tampilan halaman melakukan konsultasi dengan menambah data konsultasi pada halaman menu lalu kirim konsultasi: 


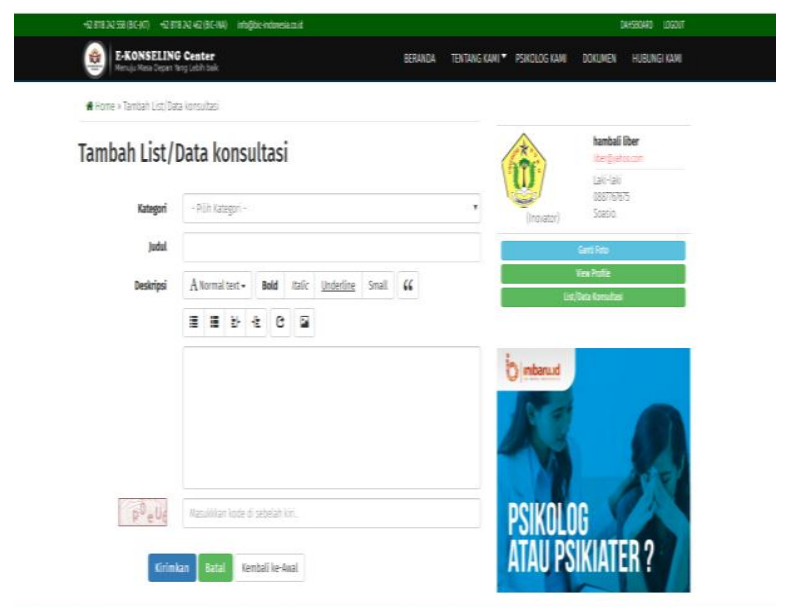

Gambar 11. Tampilan konsultasi

\section{KESIMPULAN}

Ada beberapa hal yang dapat disimpulkan dalam penelitian ini, diantarannya adalah:

1. Implementasi Aplikasi e-Konseling untuk para penderita HIV sangat bermanfaat, karena menjadi alat komunikasi yang sangat penting bagi penderita yang akan melakukan monslutasi

2. Aplikasi e-konseling mampu meberikan solusi bagi penderita HIV yang akan berkonsultasi terhadap masalah yang dihadapi.

3. Tersedianya fitur khusus untuk Konselor, sehingga, pengguna aplikasi lebih cepat mendapatkan informasi, karena konselor bisa langsung menjawab pertanyaan dengan respon cepat, karena bisa diakses dari mana saja.

\section{DAFTAR PUSTAKA}

Amani, Nazanin, 2007, Investigating The Nature, The Prevalence, And Effectiveness Of Online Counseling, A Thesis, Department of EducationalPsychology, Administratio $\mathrm{n}$ and Counseling, California State University Long Beach.

Abdurrasyid Abdurrasyid, Efy Yosrita, Fikri Amarullah, Sistem E-konseling
Terintegrasi Web Dalam Upaya Meningkatkan Kualitas Bimbingan Akademik Mahasiswa, JURNAL ILMIAH FIFO Vol 9 No 1 Tahun 2017, P-ISSN 2085-4315 E-ISSN 2502-8332

Csiernik, R., Furze, P., Dromgole, L., \& Rishchynski, G. M. (2006). Information technology and social work - The dark side or light side? Journal of Evidence-Based Social Work, 3(3-4), 9-25.

Finn, J., \& Barak, A. (2010). A descriptive study of e-counselor attitudes, ethics, and practice. Counseling and Psychotherapy Research, 10(4), 268277.

Hairil Kurniadi Siradjuddin, Implementasi Prototype Aplikasi E-Konseling Untuk Menunjang Pelayanan Konseling Berbasis Jejaring Sosial, IJIS - Indonesian Journal On Information System, Volume 2 Nomor 2 | September 2017, ISSN 2548-6438

Ifdil. (2009). Pelayanan e-Konseling (Pengolahan Hasil Pengadministrasian Alat Ungkap Masalah (AUM) dengan Menggunakan Program Aplikasi). Paper presented at the Seminar Internasional Bimbingan dan Konseling Dalam rangka Kongres XI dan Konvensi Nasional XVI ABKIN

India. (2011). Penyelenggaraan Layanan Konseling Online Sebagai Salah Satu Bentuk Pelayanan E-Konseling. Paper presented at the International Seminar \& Workshop Contemporary and Creative Caunseling. 
Konseling Online, INFO KONSELING. https://infokonseling.blogspot.com/20 13/03/konseling-online.html

M. Noval Riswandha, Nur Maulidyah, Aplikasi E-Counseling dalam Pemanfaatan Layanan bimbing dan Konseling Untuk Mengatasi Siswa Terisolir Menggunakan Metode Backward Chaining (Studi Kasus: Di SMP Negeri 2 Bangil), JURNAL LINK VOL. 26 No. 1 Februari 2017, ISSN 1858-4667

Ummu Habibah, Ekonstikurtural (EKonseling Multikultural DI Era Digital), Prosiding Seminar Nasional

Peraturan Menteri Kesehatan RI, Nomor 74, tahun 2014, tentang pedoman pelasanaan Konseling dan Tes HIV

Strategi Pelayanan Konseling Berbasis Kearifan Lokal Di Era Revolusi Industri 4.0 Kudus, 24 April 2019

Safaat, Nazruddin h. 2012. "Pemrograman Aplikasi Mobile Smartphone dan Tablet PC berbasis android, Cetakan Pertama, Edisi Revisi, Penerbit Informatika Bandung. Bandung 